\title{
Research Paper: Comprehension, Perception, and Practice of Indians about COVID-19 Anticipating the Second Wave of the Pandemic
}

Prakash Gondode $^{1^{*}}$ (D, Amrusha Raipure ${ }^{1}$ (D, Bhuvaneswari Balasubramanian ${ }^{1}$ (D), Abhinav Lambe ${ }^{1}$ (D, Omshubham Asai ${ }^{1}$ (D, Avinash Prakash ${ }^{1}$ (C)

\begin{tabular}{|l|l|}
$\begin{array}{c}\text { Use your device to scan } \\
\text { and read the article online }\end{array}$ & $\begin{array}{l}\text { Crtation Gondode P, Raipure A, Balasubramanian B, Lambe A, Asai O, Prakash A. Comprehension, Perception, and Practice } \\
\text { of Indians about COVID-19 Anticipating the Second Wave of the Pandemic. Journal of Research \& Health. 2021; 11(4):215- } \\
\text { 224. http://dx.doi.org/10.32598/JRH.11.4.1894.1 }\end{array}$ \\
dol: $:$ http://dx.doi.org/10.32598/JRH.11.4.1894.1
\end{tabular}

\section{(i) (3)}

Article info:

Received: 16 Apr 2021

Accepted: 19 May 2021

Publish: 01 Aug 2021

\section{Keywords:}

COVID-19, Pandemic, KAP,

Second wave, Knowledge, Attitude, Practice, Perception

\section{ABSTRACT}

Background: We assessed knowledge, attitudes, practice, and perceptions about COVID-19 among a convenience sample of the general public in India anticipating the second wave of the pandemic.

Methods: This questionnaire-based survey was conducted among the general population quarantined at various institutional quarantine facilities in the city of Nagpur, Maharashtra, India. Informed consent was obtained from each participant. The self-designed questionnaire comprised 25 questions regarding knowledge, eight for attitude, and ten for practice. Knowledge questions were responded to on a Yes/No basis with an additional 'don't know' option. The true answer was given 1 point and false/I don't know answers were given 0 point.

Results: The majority of the participants were aware of COVID-19 (97.9\%) and did not either wash or knew how to properly dispose of the used mask (88.02\%). Only $10.96 \%$ of the participants agreed that they verify the social media posts shared over WhatsApp and Facebook on government authentic websites before sharing them with family and friends.

Conclusion: Awareness about the virus, modes of spread, good practice, and an optimistic attitude is the prime requisite to curb the spread and to avoid the impending severity anticipating the second wave of the pandemic.

\section{Introduction

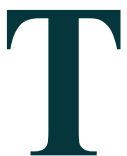 \\ he World Health Organization (WHO) acknowledged Coronavirus Disease 2019 (COVID-19) as a pandemic, the diseases have now expanded to more}

than two hundred countries, and India is one of the leading nations in the global tally for COVID-19 positive cases. India imposed lockdown strictly and started removing the lockdown in a phase-wise manner. The number of positive cases is still on the rise in India. The winter and festive seasons have further vexed the policy-

\section{"Corresponding Author:}

Prakash Gondode, MD.

Address: Department of Anaesthesiology, All India Institute of Medical Sciences, Nagpur, India.

Phone: +91 (88) 26434672

E-mail:drprakash777@gmail.com 
makers about the rise in the number of COVID-19 cases. The news of the second wave of the pandemic already hitting European countries has startled the policymakers in India. If such a second wave happens in India, it will be very grave and treacherous.

To circumvent it and to slacken its severity, it is of paramount importance that the common public along with the government takes tremendous cautiousness of selfcare and surrounding care, which can only happen with the right knowledge and a positive attitude, and good practices. The beliefs and perception should be fashioned on the foundation of facts, and not on fake news (infodemic). Most of the studies on the Knowledge, Attitudes, Practice (KAP) done in the Indian population were done on online users and the tech-savvy younger generation. Missing out a major chunk of non-internet users, we could not find any study, in which participants were from various institutional quarantine facilities. These people are at high risks and perhaps more appropriate in projecting their practices. No published literature has evaluated the KAP of the Indian population anticipating the second wave. Hence, we aimed at conducting a KAP study about COVID-19 in Indians anticipating the second wave of the pandemic.

The World Health Organization (WHO) declared COVID-19 as a global pandemic on $11^{\text {th }}$ March 2020 [1]. India currently has the largest number of confirmed cases in Asia. The countries that have already reported the peak of transmission are easing their preventive measures yet fearing the second wave of infection. The wide range of measures and preparedness, which included social distancing, social isolation, quarantine, washing hands, lockdowns, and travel bans have halted and interrupted the spread of the virus. However, the virus is still here; its transmission has been slowed but not eliminated [2]

WHO termed the flow of (mis) information as "infodemics"; within this context, if COVID-19 causes a second wave, the adverse rumors and speculations may significantly affect plans for preparedness [3]. News of the second wave of pandemic hitting Europe and the United States made rounds in late September and October adding to the trepidation $[4,5]$. Awareness about the virus, modes of spread, good practice, and an optimistic attitude are the prime requisites to curb the spread and to avoid the impending severity anticipating the second wave of the pandemic.

In several European nations, after the initial decline and subsequent relaxation of the lockdowns, the number of COVID-19 cases has again started to escalate. It is predicted that the disease is here to stay and probably may even become endemic. However, the conundrum still remains - when will the pandemic subside? To this, it has been argued that the end line may be different for different countries and will be affected by many factors, the important one being the availability of an effective and safe vaccine against COVID-19 accessible to all on a global level [6].

On Medline/PubMed/scholar search, Indian KAP about COVID-19 were mostly done on health care professionals, and in most the participants were online users only [7-10]. The knowledge and attitudes of the common masses are expected to largely influence the degree of adherence to the personal protective measures and ultimately the clinical outcome. Considering the relevance of all the above factors, this study was done to assess knowledge, attitudes, practice, and perceptions about COVID-19 among a convenience sample of the general public in India anticipating the second wave of the pandemic.

\section{Methods}

\section{Participants and data collection}

This cross-sectional study, a questionnaire-based survey was conducted among the general population quarantined at various institutional quarantine facilities in the city of central India from August 30 to October 30, 2020. Informed consent was obtained from each participant. A team of health care workers, including two doctors and two nursing staff, performed the data collection process by wearing a mask, face shield, and gloves at a well-ventilated room keeping a minimum distance of $4 \mathrm{~m}$ from the participants.

\section{Questionnaire}

The questions were established based on published literature and the official sites of WHO/MOHFW/ICMR and authors' experience of KAP, and the questionnaire was sent to five experts to consult their opinions followed by a small pilot study (with 20 participants) to test its simplicity and difficulty (Cronbach's alpha coefficient: 0.78). Demographic variables included age, gender, education, and residence. The self-designed questionnaire comprised 25 questions regarding knowledge, eight for attitude, and ten for practice. Knowledge questions were responded to on a Yes/No basis with an additional 'don't know' option. The true answer was given one point and false/I don't know answers were given 0 point. Higher scores represented better knowledge. Bloom's cut-off points scoring was used to denote good, moderate and poor scoring. With 
score between $100 \%$ to $80 \%$ as good, $79.99 \%$ to $60 \%$ as moderate and less than $60 \%$ as poor knowledge scores.

\section{Statistical analysis}

Statistical analyses were performed using SPSS v. 22. KAP scores were tested for normality of distribution. Data were expressed as Mean \pm SD and categorical data were expressed as frequency and percentage. Comparison of KAP scores among the participants with respect to various demographic variables was done using an independent samples t-test and One-Way Analysis of Variance (ANOVA). In this study, P-value $<0.05$ was statistically significant.

\section{Results}

\section{Demographic characteristics}

Table 1 depicts the demographic characteristics of the study population. Out of the 684 participants, $51.02 \%$ were males. Only less than $10 \%$ of the participants were from rural areas.

\section{Knowledge}

The results of the knowledge survey are presented in Table 2 (Questions 1 to 25). The majority of the participants were aware of COVID-19 (97.9\%). More than $80 \%$ of the study population knew that neither vitamin and mineral supplement nor malaria drug Hydroxychloroquine cures the disease. The overall score of the participants was 18.7 out of 22, which shows a good knowledge of the study population about COVID-19.

\section{Attitude}

Table 2 (Questions 26 to 33) shows that there has been a change in the attitude towards healthy eating and general and personal hygiene after COVID-10 (88\% and 94\% respectively). The majority of the subjects were worried about the risk of cross-transmission to others, while $12 \%$ had difficulty in sleeping due to the worries about the ongoing pandemic. Also, $85.9 \%$ of the participants showed trust in the measures taken by the government and $87.8 \%$ believed that lessons learned from this pandemic will prepare us better to prevent a similar global pandemic.

\section{Practice}

Table 2 (questions 34 to 43) represents the responses to the practice questions. About $26.9 \%$ of the participants were using the Arogya setu app by the government of India. The majority of the participants did not either wash or knew how to properly dispose of the used mask
$(88.02 \%)$. Only $10.96 \%$ of the participants agreed that they verified the social media posts shared over WhatsApp and Facebook on government authentic websites before sharing them with family and friends.

\section{Perception}

Participants were asked how they feel about the pandemic now versus the time when they first heard of it. They were asked to choose freely (one or more) from the options, like angry, nervous, scared, stressed, relaxed, optimistic, or happy (Figure 1). Participants were asked about the reason for the continuous rise of cases in India regardless of the efforts taken by the government (Figure 2).

Analysis of KAP scores with respect to demographic characteristics

Table 3 describes the scores of KAP towards COVID-19 concerning demographic variables, such as gender, age, residence, and education. The knowledge scores of the female subjects were slightly higher than those of males; however, the difference was not significant $(\mathrm{P}>0.05)$. Higher scores of females were observed in th attitude and practice compared with that of males. In addition, the difference in attitude score was significant between different genders $(\mathrm{P}<0.05)$. The elderly age group (more than 60 years) showed lower scores in the scores of KAP compared with the other groups. Participants residing in the urban areas showed higher scores in KAP, and the difference was significant regarding attitude $(\mathrm{P}<0.05)$.

\section{Discussion}

Better knowledge and awareness about a situation influences attitude and practices. In this study, we found that as high as $97.9 \%$ of the participants were aware of the ongoing pandemic of COVID-19. The major sources of information were television news channels and radio, followed by social media and newspapers. This is similar to the findings in a study conducted by Narayana et al. [11].

The participants had good knowledge about the fake news and myths about the COVID-19 pandemic. Around $88.89 \%$ of participants knew about WHO, MoHFW, ICMR, State government health portals, and Arogya setu app as authentic sources for information. But, only $10.96 \%$ of the population agreed that they have verified posts shared on WhatsApp and social media. Several sites, like WHO, MoHFW, ICMR, and State government health portals, and Arogya setu app are providing myth busters and authentic information. Governments are also urging people to not sharing these messages without checking their authenticity. 
Table 1. Demographic details of the participants

\begin{tabular}{|c|c|c|}
\hline \multicolumn{2}{|c|}{ Variables } & \multirow{2}{*}{$\begin{array}{c}\text { No. (\%) } \\
349(51.02)\end{array}$} \\
\hline Gender & Male & \\
\hline हैince & Female & 335 (48.98) \\
\hline \multirow{3}{*}{ Age - category (Years) } & $18-30$ & 199 (29.09) \\
\hline & $30-60$ & $388(56.73)$ \\
\hline & $60<$ & $97(14.18)$ \\
\hline \multirow{2}{*}{ Residence } & Urban & $621(90.79)$ \\
\hline & Rural & $63(9.21)$ \\
\hline \multirow{4}{*}{ Education } & Illiterate & $67(9.79)$ \\
\hline & Reading and writing ability & $72(10.53)$ \\
\hline & Elementary & $386(56.43)$ \\
\hline & Secondary and above & $159(23.25)$ \\
\hline
\end{tabular}

WMI

The stigma related to the disease is evident by the observation that $61.99 \%$ of participants feared the risk of getting the infection from a healthcare worker living in their proximity. Also, $75 \%$ of the participants had fear of expulsion from society, if they declare to have symptoms. As COVID-19 is a new disease, its emergence and spread can cause confusion, anxiety, and fear. Fear is the breeding ground for hatred and stigma. Social stigma has arisen as certain populations are targeted as being the reason for this outbreak. It is vital to avoid this stigma as it can make people hide their illness and not seek health care immediately [12].

The current study found that $88.89 \%$ of participants felt that they have become more conscious about their healthy eating habits. A higher percentage (94.88\%) of people had positive changes in their attitude as far as personal and surrounding hygiene is concerned. Several studies have similar findings of change in eating habits and lifestyle modifications during the COVID-19 pandemic $[13,14]$. In this study, $12 \%$ of the participants had sleeping difficulties due to worry about COVID-19, which can be attributed to economic crisis-related stress, social and travel restrictions, changes in daily life, and mental illness [15].

This study displayed good practices in the participants, as $97.95 \%$ of the population were using face masks when going outdoors, but the majority of the participants $(88.02 \%)$ did not know about proper disposal or about regular washing of cloth masks after use. India is the largest medical waste generator in Asia [16]. The recommendations by the government for proper disposal are seldom followed and hence, this could be another factor in the spread of the infection. It is of prime importance to make people aware of the risks of infection spread and the importance of proper disposal of masks [17].

The world's battle against the novel coronavirus pandemic has seen heavy reliance on technology. Arogya Setu, COVID 19 Feedback, MyGov, SAHYOG, COVID-19 Quarantine Monitor- Tamil Nadu, COVA Punjab, and Test yourself Goa are some of the apps that are developed by the state and central government, of which Arogya setu app is most commonly used [18]. The app is loaded with authentic information and easy-to-use features, but in this study, we found only $26.90 \%$ of the participants used the app, and a need was felt to further encourage the use of this informative app to the public.

The perception of participants regarding COVID-19 has changed from the initial months. Participants were more scared and stressed in the initial months and gradually, positive feelings augmented. This change in perception can be attributed to the increase in knowledge about the virus and the disease, the mode of spread, and the belief and rise in the trust in the measures taken by the government at various fronts.

Regarding the reasons for India's continuous rise in cases, the participants pointed out various reasons, including the fear of hospitalization and the stigma related to the isolation that stops people from approaching timely health care leading to the more spread of the disease. Another common reason, which participants perceived was the casual attitude of the public in general, which is mainly because the majority of the infected individuals are only mild cases and have minimal symptoms, resulting in a casual approach and non-adherence to the 
Table 2. Results of the knowledge, Attitude, and Practice survey $(n=684)$

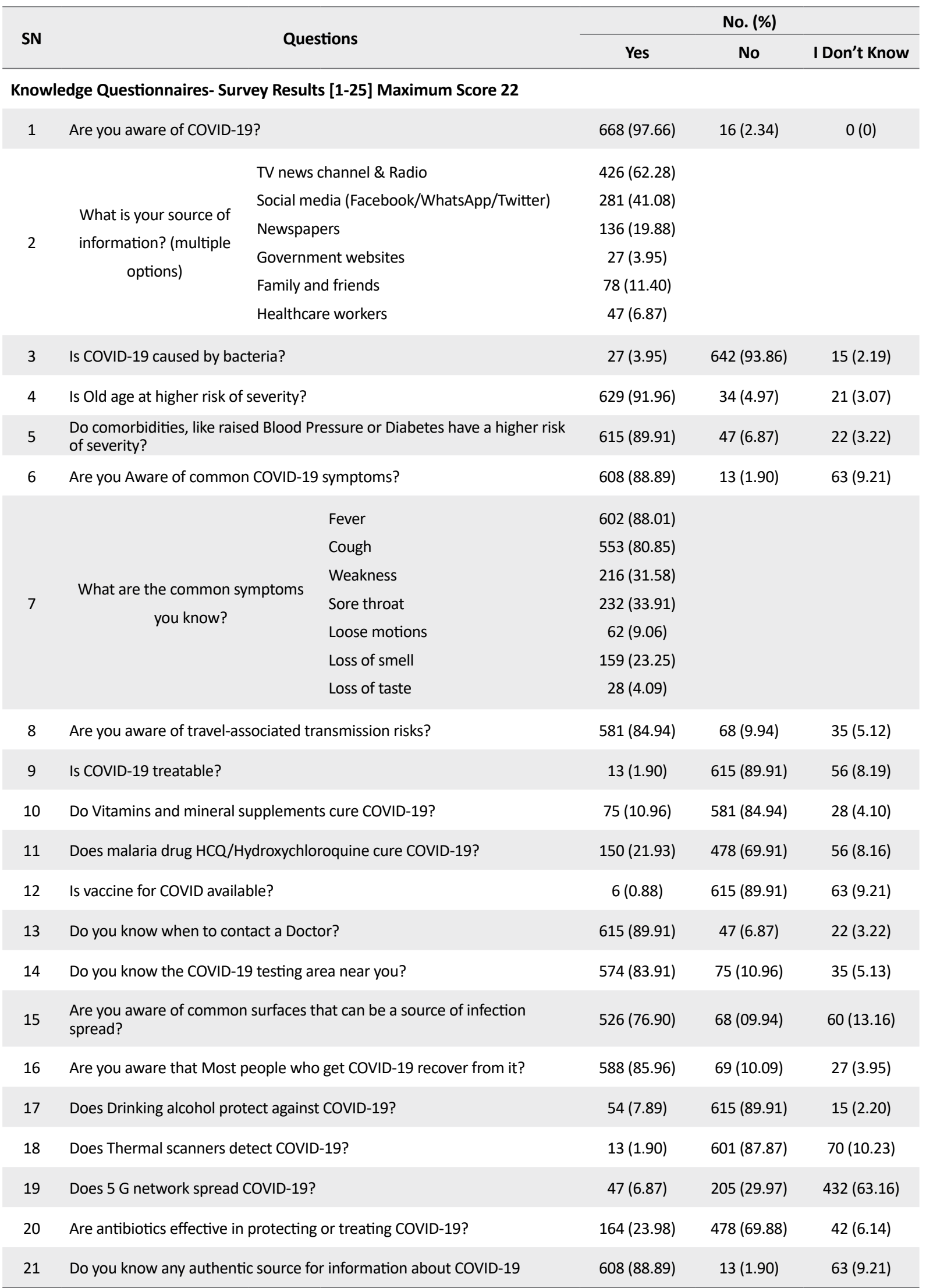




\begin{tabular}{|c|c|c|c|c|c|}
\hline \multirow{2}{*}{ SN } & \multirow{2}{*}{\multicolumn{2}{|c|}{ Questions }} & \multicolumn{3}{|c|}{ No. (\%) } \\
\hline & & & Yes & No & I Don't Know \\
\hline \multirow{5}{*}{22} & \multirow{5}{*}{$\begin{array}{l}\text { What are the authentic sources for } \\
\text { information? }\end{array}$} & WHO & $287(41.96)$ & & \\
\hline & & MOHFW & $41(5.99)$ & & \\
\hline & & ICMR & $6(0.88)$ & & \\
\hline & & State government health portal & $225(32.89)$ & & \\
\hline & & Arogya Setu app & $184(26.90)$ & & \\
\hline 23 & \multicolumn{2}{|c|}{$\begin{array}{l}\text { Can a person with COVID-19 transmit the virus to others when fever is not } \\
\text { present? }\end{array}$} & $615(89.91)$ & $20(2.92)$ & $49(7.17)$ \\
\hline 24 & \multicolumn{2}{|c|}{ Can COVID-19 spread via respiratory droplets of infected individuals? } & $629(91.96)$ & $27(3.95)$ & $28(4.09)$ \\
\hline 25 & \multicolumn{2}{|c|}{ Covid-19 symptoms appear within 2-14 days } & $492(71.93)$ & $68(9.94)$ & $124(18.13)$ \\
\hline \multicolumn{6}{|c|}{ Attitude Questionnaires- Survey Results [26-33] Maximum Score 8} \\
\hline 26 & \multicolumn{2}{|c|}{ Have you become more conscious about healthy eating habits? } & $608(88.89)$ & $54(7.89)$ & $22(3.22)$ \\
\hline 27 & \multicolumn{2}{|c|}{ Have you become more conscious about self and surroundings hygiene? } & $649(94.88)$ & $27(3.95)$ & $8(1.17)$ \\
\hline 28 & \multicolumn{2}{|c|}{ Are you having difficult sleep due to worry about COVID-19? } & $82(11.99)$ & $567(82.89)$ & $35(5.12)$ \\
\hline 29 & \multicolumn{2}{|c|}{ Are you worried about the cross-infection to other family members? } & $588(85.96)$ & $82(11.99)$ & $14(2.05)$ \\
\hline 30 & \multicolumn{2}{|c|}{$\begin{array}{l}\text { Are you scared of getting the disease from a healthcare worker who lives } \\
\text { near You? }\end{array}$} & 424 (61.99) & 205 (29.97) & $55(8.04)$ \\
\hline 31 & \multicolumn{2}{|c|}{ Are you afraid of expulsion from society if you get infected? } & $513(75.00)$ & $143(20.91)$ & $28(4.09)$ \\
\hline 32 & \multicolumn{2}{|c|}{ Do you think the government is doing enough to stop the pandemic? } & $588(85.96)$ & $61(8.92)$ & 35 (5.12) \\
\hline 33 & \multicolumn{2}{|c|}{$\begin{array}{l}\text { Do you think the lessons learned from this pandemic will prepare us better } \\
\text { to prevent a similar global pandemic? }\end{array}$} & 601 (87.87) & $13(1.90)$ & 70 (10.23) \\
\hline
\end{tabular}

Practice Questionnaires- Survey Results [34-43] Maximum Score 10. Only Two Options Yes/No

\section{Questions}

34

35 Are you using disinfectant/sanitizer at home?

36 Do you cover your nose/mouth while coughing/sneezing?

37 Are you maintaining social distancing?

38 Are you avoiding social gatherings and meetings?

39 Are you using face masks when going outdoors?

40 Do you wash/dispose of the masks after every use?

41 Are you wearing the mask during exercises?

42 Are you using Arogya setu app?

43 Do you verify WhatsApp/Social media posts about COVID-19 on authentic websites (like WHO/ICMR/MOHFW/State Govt. Portals)
Yes

$663(96.92)$

21 (3.08)

492 (71.92)

$192(28.08)$

$656(95.90)$

28 (4.10)

629 (91.95)

55 (8.05)

649 (94.88)

35 (5.12)

670 (97.95)

14 (2.05)

$82(11.98) \quad 602(88.02)$

$259(37.86) \quad 425(62.14)$

$184(26.90) \quad 500(73.10)$

$75(10.96) \quad 609$ (89.04) 


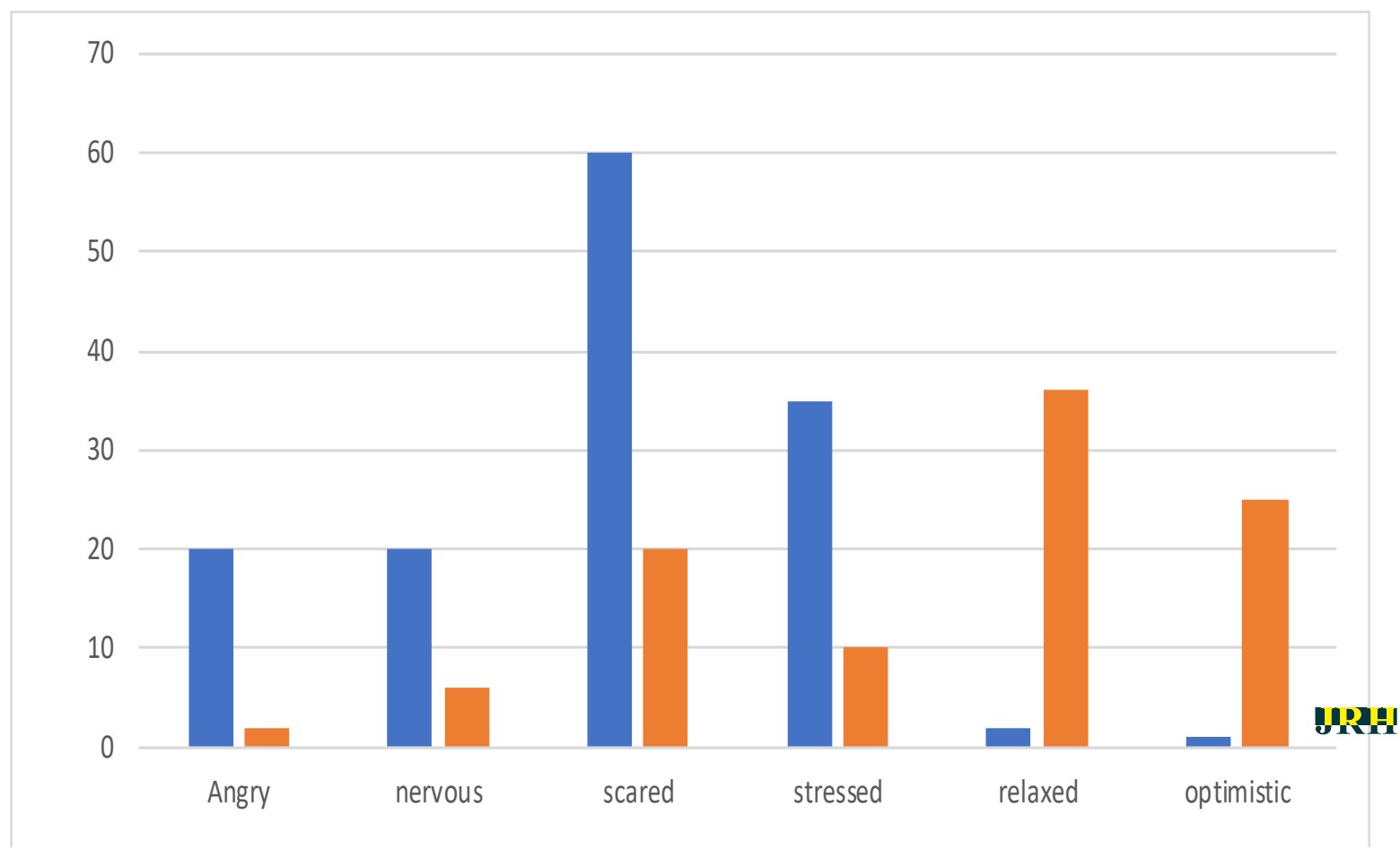

Figure 1. Changes in the general feeling/perception of the participants from the beginning of the pandemic to date [AugOctober 2020]

Footnote: Perception responses of the participants to the question: 'How did you feel about the pandemic in Feb- March when you first heard of it? And How do you feel about the pandemic now?' (Angry/Nervous/scared/stressed/relaxed/optimistic/happy).

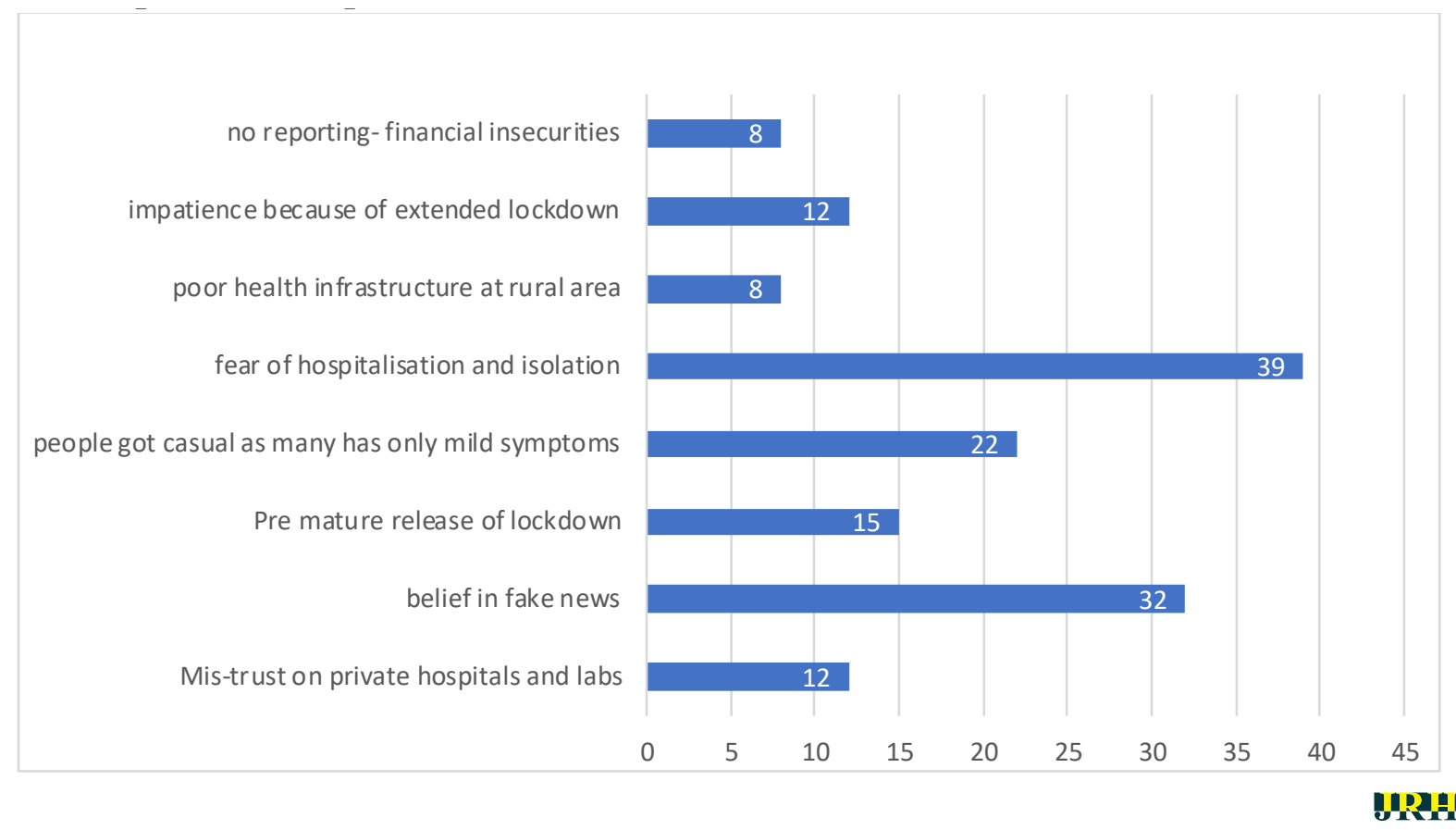

Figure 2. Various reasons for India's rise in cases [participant's most common responses to an open-ended question]

Footnote: Perception responses of the participants to the question: Irrespective of all the efforts taken by the government of India, what do you think is the reason for the continuous rise of cases in India? [Open ended]. 
Table 3. Comparison of knowledge, attitude, and practice scores among different demographic variables

\begin{tabular}{|c|c|c|c|c|c|c|c|c|c|c|}
\hline \multirow{2}{*}{\multicolumn{2}{|c|}{ Variables }} & \multicolumn{3}{|c|}{ Knowledge Scores } & \multicolumn{3}{|c|}{ Attitude Scores } & \multicolumn{3}{|c|}{ Practice Scores } \\
\hline & & Mean $\pm S D$ & $\mathbf{F}$ & $\mathbf{P}$ & Mean $\pm S D$ & $\mathbf{F}$ & $\mathbf{P}^{*}$ & Mean $\pm S D$ & $\mathbf{F}$ & $\mathbf{P}$ \\
\hline Gender & $\begin{array}{l}\text { Male } \\
\text { Female }\end{array}$ & $\begin{array}{l}18.23 \pm 3.8 \\
18.69 \pm 3.6\end{array}$ & 1.11 & 0.319 & $\begin{array}{l}6.44 \pm 0.8 \\
6.57 \pm 0.9\end{array}$ & 1.27 & 0.030 & $\begin{array}{l}6.78 \pm 3.7 \\
6.92 \pm 3.6\end{array}$ & 1.05 & 0.614 \\
\hline $\begin{array}{l}\text { Age Cat- } \\
\text { egory (Y) }\end{array}$ & $\begin{array}{c}18-30 \\
30-60 \\
60<\end{array}$ & $\begin{array}{l}18.59 \pm 3.1 \\
18.47 \pm 3.5 \\
17.98 \pm 3.2\end{array}$ & 1.13 & 0.323 & $\begin{array}{l}6.51 \pm 1.0 \\
6.59 \pm 1.1 \\
6.19 \pm 0.9\end{array}$ & 5.68 & $0.003^{\#}$ & $\begin{array}{l}6.49 \pm 3.6 \\
6.52 \pm 3.2 \\
6.38 \pm 3.5\end{array}$ & 0.06 & 0.934 \\
\hline Residence & $\begin{array}{l}\text { Urban } \\
\text { Rural }\end{array}$ & $\begin{array}{l}18.98 \pm 3.7 \\
18.05 \pm 3.2\end{array}$ & 1.34 & 0.153 & $\begin{array}{l}6.61 \pm 1.0 \\
6.11 \pm 1.2\end{array}$ & 1.44 & 0.037 & $\begin{array}{l}6.89 \pm 3.5 \\
6.50 \pm 3.6\end{array}$ & 1.06 & 0.725 \\
\hline Education & $\begin{array}{c}\text { Illiterate } \\
\text { Reading and writ- } \\
\text { ing ability } \\
\text { Elementary } \\
\text { Secondary and } \\
\text { above }\end{array}$ & $\begin{array}{l}17.18 \pm 2.8 \\
17.73 \pm 3.2\end{array}$ & 5.77 & $<0.001^{+}$ & $\begin{array}{c}6.51 \pm 0.9 \\
6.60 \pm 0.99\end{array}$ & 10.01 & $<0.001^{\#}$ & $\begin{array}{l}6.86 \pm 3.3 \\
6.91 \pm 3.2\end{array}$ & 1.09 & 0.354 \\
\hline
\end{tabular}

URA

${ }^{*} \mathrm{P}<0.05$ is statistically significant; Tukey's post-hoc test confidence intervals: $95 ; \# 30-60$ years vs over 60 years $(\mathrm{P}=0.0022)$; + Illiterate vs Elementary $(\mathrm{P}=0.0064)$ and Illiterate vs Secondary and above $(\mathrm{P}=0.0019)$; \# Illiterate vs Elementary $(\mathrm{P}=0.0002)$ and Illiterate vs Secondary and above $(\mathrm{P}=0.0001)$; Reading and Writing ability vs Elementary $(\mathrm{P}=0.0082)$ and Reading and Writing ability vs Secondary and above $(\mathrm{P}=0.0024)$.

general advisory of using face masks, practicing social distancing, and avoiding gatherings and crowd. Another common reason was a blind belief in fake news.

\section{Conclusion}

Our study findings strongly suggest there are still so many areas, which should be given proper attention to stop the severity of the second wave of the pandemic. People should be made aware of the fact that a casual approach will cause more danger and harm, and there should be strict abiding to the use of masks in public places and following social distancing. Fake news can cause more harm and result in anxiety and fear. There is a need for social media users to confirm the authenticity of the information they come across as well as share on social media. This can be achieved through considering the source of information, reading beyond the headlines, checking the authors, indepth investigation of the news article by checking the dates, examining evidence to confirm enough facts and figures, confirming fake images, searching other sources, and asking professionals when in doubt.
There is an urgency to educate people and spread the awareness of proper disposal of used masks or the washing of reusable masks. Mental health support should be provided to those with disturbed sleep and in need. Education is the only solution to curb the stigma and to encourage people to report to the institutions if they are symptomatic or have a history of exposure. The countries who are already planning about easing the stringent preventive measures should thoroughly revisit the entire situation, not only of their own country but also the entire world. In this regard, scientists, including epidemiologists (to study the characteristics of the COVID-19) and medical anthropologists (to analyze the patterns of human behaviors, e.g. rumors, that may affect the programs of preparedness), should be engaged to deeply analyze the situation and formulate comprehensive plans to deal with the pandemic.

\section{Ethical Considerations}

\section{Compliance with ethical guidelines}

This study was approved by the Research Council of all India Institute of Medical Sciences, Nagpur, India, 
and by the Institute Ethical Committee [Approval number: IEC/Pharmac/116/20;14/05/20].

\section{Funding}

This research did not receive any grant from funding agencies in the public, commercial, or non-profit sectors.

\section{Authors' contributions}

Study design: Prakash Gondode, Amrusha Raipure, and Bhuvaneswari Balasubramanian; Data collection and analysis: Prakash Gondode, Omshubham Asai, Abhinav Lambe; Manuscript preparation: Prakash Gondode, Abhinav Lambe, Bhuvaneswari Balasubramanian; Critical review: Prakash Gondode, Avinash Prakash.

\section{Conflict of interest}

The authors declared no conflict of interest

\section{References}

[1] WHO. WHO Director-General's opening remarks at the media briefing on COVID-19 [Internet]. 2021 [Updated 2021 April 6]. Available from: https://www.who.int/directorgeneral/speeches/detail/who-director-general-s-openingremarks-at-the-media-briefing-on-covid-19---11-march-2020

[2] Ali I. COVID-19: Are we ready for the second wave? Disaster Med Public Health Prep. 2020; 14(5):e16-8. [DOI:10.1017/ dmp.2020.329] [PMID]

[3] World Health Organization (WHO). Novel Coronavirus (2019-nCoV) situation report - 13 [Internet]. 2020 [Updated 2021 April 6]. Available from: World Health Organization website. https://www.who.int/docs/default-source/coronaviruse/situation-reports/20200202-sitrep-13-ncov-v3.pdf

[4] Sinha A. Europe's second wave of Covid-19: A look at trends, and possible causes [Internet]. 2020 [Updated 2021 November 6]. Available from: https://indianexpress.com/article/explained/ explained-europes-second-covid-19-wave-6910627/

[5] Moneycontrol News. Coronavirus second wave | US, Italy, other countries back under restrictions, lockdowns, and curfews [Internet]. 2020 [Updated 2021 April 6]. Available from: https://www.moneycontrol.com/news/world/coronavirus-update-us-italy-other-countries-witness-record-high-assecond-wave-of-covid-19-surges-6008771.html

[6] Scudellari M. How the pandemic might play out in 2021 and beyond. Nature. 2020; 584(7819):22-5. [DOI:10.1038/d41586020-02278-5] [PMID]

[7] Arora S, Abullais Saquib S, Attar N, Pimpale S, Saifullah Zafar K, Saluja P, et al. Evaluation of knowledge and preparedness among indian dentists during the current COVID-19 pandemic: A cross-sectional study. J Multidiscip Healthc. 2020; 13:841-54. [DOI:10.2147/JMDH.S268891] [PMID]
[8] Parikh PA, Shah BV, Phatak AG, Vadnerkar AC, Uttekar S, Thacker N, et al. COVID-19 pandemic: Knowledge and perceptions of the public and healthcare professionals. Cureus. 2020; 12(5):e8144. [DOI:10.7759/cureus.8144] [PMID]

[9] Gohel KH, Patel PB, Shah PM, Patel JR, Pandit N, Raut A. Knowledge and perceptions about COVID-19 among the medical and allied health science students in India: An online crosssectional survey. Clin Epidemiol Glob Health. 2021; 9:104-9. [DOI:10.1016/j.cegh.2020.07.008] [PMID]

[10] Maheshwari S, Gupta PK, Sinha R, Rawat P. Knowledge, attitude, and practice towards Coronavirus Disease 2019 (COVID-19) among medical students: A cross-sectional study. J Acute Dis. 2020; 9(3):100-4. [DOI:10.4103/2221-6189.283886]

[11] Narayana G, Pradeepkumar B, Ramaiah JD, Jayasree T, Yadav DL, Kumar BK. Knowledge, perception, and practices towards COVID-19 pandemic among general public of India: A cross-sectional online survey. CMRP. 2020; 10(4):153-9. [DOI:10.1016/j.cmrp.2020.07.013] [PMID] [PMCID]

[12] Roy D, Tripathy S, Kar SK, Sharma N, Verma SK, Kaushal V. Study of knowledge, attitude, anxiety \& perceived mental healthcare need in Indian population during COVID-19 pandemic. Asian J Psychiatr. 2020; 51:102083. [DOI:10.1016/j. ajp.2020.102083] [PMID]

[13] Kumar M, Dwivedi S. Impact of Coronavirus imposed lockdown on Indian population and their habits. Int J SciHealthc Res. 2020; 5(2):88-97. https://d1wqtxts1xzle7. cloudfront.net/63816196/IJSHR001320200703-43187-vow2lawith-cover-page-v2.pdf?Expires $=1629798059 \&$ Signature=AEvmnNFXIBnqE2sIqX5bL5Qfia4OSpWmwy4P2xyjW0sHcMg3kKXCMTBZqeg3mtdaMfuUoeLkrgyY7au0XLUc2T

[14] Di Renzo L, Gualtieri P, Pivari F, Soldati L, Attinà A, Cinelli $\mathrm{G}$, et al. Eating habits and lifestyle changes during COVID-19 lockdown: An Italian survey. J Transl Med. 2020; 18(1):229. [DOI:10.1186/s12967-020-02399-5] [PMID]

[15] Brooks SK, Webster RK, Smith LE, Woodland L, Wessely S, Greenberg N, et al. The psychological impact of quarantine and how to reduce it: Rapid review of the evidence. Lancet 2020; 395(10227):912-20. [DOI:10.1016/S0140-6736(20)30460-8] [PMID]

[16] Sangkham S. Face mask and medical waste disposal during the novel COVID-19 pandemic in Asia. Case Stud Chem Environ Eng. 2020; 2:100052. [DOI:10.1016/j.cscee.2020.100052]

[17] Bandela D. COVID-19: Here is what you should do to safely dispose your used mask [Internet]. 2020 [Updatd 2021 April 61]. Available from: https://www.downtoearth.org. in/news/waste/covid-19-\%20collection

[18] Sengupta A. Gadgets 360- an NDTV venture. Coronavirus Apps: Every App the Central Government and States Have Deployed to Track COVID 19. [Internet] 2020 [Updated 2020 April 01]. Available from: https://gadgets.ndtv.com/apps/ features/central-state-governments-launch-coronavirus-mobile-app-list-2204286 
This Page Intentionally Left Blank 